\title{
Feeding habits of the first European colobine, Mesopithecus (Mammalia, Primates): evidence from a comparative dental microwear analysis with modern cercopithecids
}

\author{
Gildas MERCERON \\ UMR 5125 PEPS, CNRS, \\ Université Claude Bernard Lyon 1, Campus de la Doua, GEODE, \\ 2, rue Raphaël Dubois, F-69622 Villeurbanne Cedex (France) \\ gildas.merceron@univ-lyon1.fr \\ George D. KOUFOS \\ Aristotle University of Thessaloniki, \\ Department of Geology, Laboratory of Geology and Palaeontology, \\ GR-54124 Thessaloniki (Greece) \\ koufos@geo.auth.gr \\ Xavier VALENTIN \\ UMR 6046 CNRS, Institut international de Paléoprimatologie, \\ Paléontologie humaine: Évolution et Paléoenvironnements, CNRS, \\ and Université de Poitiers, \\ 40, avenue du recteur Pineau, F-86022 Poitiers cedex (France) \\ xavier.valentin@univ-poitiers.fr
}

KEY WORDS

Mammalia,

Primates,

Cercopithecoids,

Neogene,

Europe,

diet,

ecology.
Merceron G., Koufos G. D. \& Valentin X. 2009. - Feeding habits of the first European colobine, Mesopithecus (Mammalia, Primates): evidence from a comparative dental microwear analysis with modern cercopithecids. Geodiversitas 31 (4): 865-878.

\section{ABSTRACT}

This study aims to characterize the feeding habits of the first European colobines, Mesopithecus (late Miocene), through the analysis of its molar microwear pattern. Fifty-seven adult individuals of Mesopithecus (from Greece and Bulgaria) are compared to 162 wild-shot specimens representing nine modern species of African and Asian cercopithecids. Through the combination of a principal component analysis and analyses of variances, Mesopithecus displays significant differences with its extant colobine relatives. Actually, there is no significant difference between the Mesopithecus samples and Chlorocebus aethiops and Papio hamadryas. An intra-specific test dedicated to Mesopithecus pentelicus reveals no difference between the Bulgarian and the Greek samples. To sum up, the species of Mesopithecus were not leaf eaters like their present-day colobine relatives. Considering its wide paleogeographic range, its post-cranial anatomy, the paleoenvironmental data, and the present dietary reconstruction as a whole, the species of Mesopithecus can be depicted as semi-terrestrial monkeys opportunists in term of feeding preferences. 


\author{
MOTS CLÉS \\ Mammalia, \\ Primates, \\ Cercopithécoïdes, \\ Néogène, \\ Europe, \\ alimentation, \\ écologie.
}

\begin{abstract}
RÉSUMÉ
Habitudes alimentaires du premier colobiné européen, Mesopithecus: apports de l'analyse comparative des micro-usures dentaires avec des cercopithecidés actuels.

Cette étude vise à déterminer les habitudes alimentaires des premiers colobinés européens, du genre Mesopithecus (Miocène supérieur) par l'analyse du type de micro-usure dentaire sur les molaires. Cinquante-sept spécimens attribués à Mesopithecus sont comparés à 162 individus sauvages représentant neuf espèces actuelles de cercopithécidés africains et asiatiques. À travers une analyse en composante principale couplée à des analyses de variances, Mesopithecus apparaît significativement différent des colobinés actuels. Aucune différence significative n'est détectée entre les Mesopithecus et Chlorocebus aethiops et Papio hamadryas. Une analyse interspécifique dédicacée à Mesopithecus pentelicus ne révèle aucune différence entre les échantillons bulgares grecs. En résumé, les espèces de Mesopithecus se distinguent des colobinés actuels, principalement folivores. En prenant en compte les données paléoenvironnementales, leur distribution paléogéographique, leur anatomie postcrânienne, et leurs habitudes alimentaires ici reconstituées, les Mesopithecus peuvent être dépeints comme des singes semiterrestres et généralistes vis-à-vis de leur bol alimentaire.
\end{abstract}

\section{INTRODUCTION}

From the late Miocene to Pleistocene, cercopithecids have known a high specific diversity in Western Eurasia. Four genera are known: Macaca Lacépède, 1799, Paradolichopithecus Necrasov, Samson \& Rădulescu, 1961, Dolichopithecus Depéret, 1889, and Mesopithecus Wagner, 1839. Mesopithecus from the late Miocene is the first representative of the family in Europe. The first occurrence of the genus was traced at Wissberg (Germany) dated to early Vallesian (MN 9). However, as Andrews et al. (1996) claim, the sole known teeth of Wissberg may come from different Dinotherium-Sands horizons with different ages. Actually, Mesopithecus is known from Turolian deposits. The genus is recognized at Grossulovo (Ukraine), an early Turolian locality (Semenov 2001) for which no independent age calibration has been performed. Mesopithecus from the locality "Ravin des Zouaves 5", RZO of Axios Valley (Macedonia, Greece) is therefore the first reliable occurrence of the genus in Europe (Bonis et al. 1990). The faunal assemblage from this locality is dated to the lower part of the early Turolian (late Miocene, 8.7-7.5 Ma); the magnetostratigraphy sug- gests a correlation to Chron C4r.1r (8.23-8.07 Ma) indicating an age of $-8.2 \mathrm{Ma}$ (Koufos 2006a). The genus Mesopithecus was also recognized in the locality Nikiti 2 (Koufos 2009, this volume). The locality is dated to the lowermost early Turolian, MN 11 (Koufos 2006a) confirming the certain early Turolian appearance of Mesopithecus in Eurasia. Mesopithecus is recognized as an early colobine; Microcolobus tugenensis Benefit \& Pickford, 1986 from $11 \mathrm{Ma}-$ deposits of Kenya is probably the first representative of the subfamily (Benefit \& Pickford 1986). The cranial and dental features root Mesopithecus at the knot splitting colobini and presbytini tribes (Szalay \& Delson 1979; Strasser \& Delson 1987; Bonis et al. 1990). Whereas the 10 modern genera of colobines are only distributed in Asia and Africa (Rowe 1996), Mesopithecus was widespread from France to Pakistan (with the exception of Anatolia) during the Turolian (Heintz et al. 1981; Andrews et al. 1996; Harrison \& Delson 2007).

The paleobiology of Mesopithecus is particularly interesting because its occurrence in Eurasia is more or less synchronous to the extinction of the Miocene hominoids (Andrews et al. 1996). Two main hypotheses can explain this synchronism: changes in 
climate and vegetation at the end of the Vallesian (Bonis et al. 1999; Agustí et al. 2003; Nelson 2003; Merceron et al. 2005a; Koufos 2006c) and/or direct ecological competition between the hominoids and cercopithecoids. The lack of co-occurrence of both hominoids and cercopithecoids rather supports the first hypothesis. Recently an isolated hominoid tooth assigned to cf. Ouranopithecus Bonis \& Melentis, 1977 was discovered in the Bulgarian locality of Azmaca dated to Turolian ages (Spassov \& Geraads 2008). Mesopithecus is hitherto absent in this locality but bearing in mind that this monkey is quite well known in the Turolian of Bulgaria (Koufos et al. 2003), it would support a co-existence of cercopithecoids and hominoids in Eastern Europe at least.

Contrary to the cercopithecines, the modern colobines are more involved in folivory (Rowe 1996 and citations therein). Besides, they display peculiar anatomical features of their gastrointestinal tracts. They have a forestomach which is divided into a proximal presaccus and a saccus (for complete review of gastrointestinal tract, see Chivers 1994; Kay \& Davies 1994; Lambert 1998). A low acidity rate in these two former chambers is required to maintain fermentation in optimal conditions. During fermentation, carbohydrates, and especially polysaccharides (e.g., cellulose from the plant cellwalls) are reduced into disaccharide sugars, which are easily hydrolyzed during the transit through the small intestine before absorption. Chivers (1994) and Kay \& Davies (1994) suspect that the folivory amongst colobines may have arisen from diets rich in seeds. This hypothesis is based on two facts. First, the two oldest cercopithecoids, Prohylobates Fourtau, 1918 and Victoriapithecus von Koenigswald, 1969, were not highly involved in folivory since they have cercopithecine-like molars (Benefit 2000). Second, fruits do not usually have complex molecules difficult to digest whereas seeds have many carbohydrates as complex as those found in foliage. This means that seeds might have been a link between frugivory and folivory (Chivers 1994).

Thus the question is, was Mesopithecus a leaf eater like its modern relatives or a fruit/seed eater as the extant cercopithecines? The present article is an effort to answer to this question trying to estimate the dietary habits and therefore its palaeobiology, using dental microwear. Dental microwear, the study of scars on enamel facets resulting from abrasion with food items gives direct information of what an individual ate over a period of time in the past (Walker et al. 1978; Teaford \& Oyen 1989).

\section{ABBREVIATIONS USED IN TEXT \\ PCA Principal Component Analysis; \\ LSD test Fischer's Least Significant Differences test; \\ HSD test Tukey's Honest Significant Differences test; \\ Nfs, Nws Number of fine and wide scratches, re- spectively; \\ Nlp, Nsp Number of large and small pits respec- tively; \\ Np, Pp Number and percentage of pits, respec- tively: \\ Ns, Ls Number and length of scratches respec- tively.}

$\begin{array}{ll}\text { Localities } & \\ \text { HD } & \text { Hadjidimovo-1 locality; } \\ \text { K } & \text { Kalimantsi locality; } \\ \text { PER } & \text { Perivolaki locality; } \\ \text { PIK } & \text { Pikermi locality; } \\ \text { RZO } & \text { Ravin des Zouaves-5 locality; } \\ \text { VTK } & \text { Vathylakkos-2 locality. }\end{array}$

Institutions

AMPG Athens Museum of Palaeontology and Geology;

MNHN Muséum nationale d'Histoire naturelle, Paris;

MNHN-CG Specimens from the "Catalogue général" housed in MNHN;

NHMW Naturhistorisches Museum, Wien;

RMCA Royal Museum of Central Africa, Tervuren;

ZSM Zoologische Staatssammlung of Munich;

SNG Naturmuseum Senckenberg, Frankfurt.

\section{MATERIAL}

A total number of 57 adult individuals of Mesopithecus (Appendix 1) are studied in this article. They belong to various Greek and Bulgarian Turolian localities. This fossil material is housed in the following European museum or institutions: the Assenovgrad Museum, a paleontological division of the National Museum of Natural History of Sofia (Bulgaria), the Muséum national d'Histoire naturelle, Paris (France), the Naturhistorisches Museum in Wien (Austria), the University of Vienna (Austria), the Athens $\mathrm{Mu}$ - 
TABLE 1. - Dietary composition of extant cercopithecids.

\begin{tabular}{|c|c|c|}
\hline Name & Diet & Publications \\
\hline Chlorocebus aethiops & Fruits, seeds, leaves, animal prey & $\begin{array}{l}\text { Struhsaker 1967; Rowe 1996; Nakawaga 2003; } \\
\text { Lambert } 2005\end{array}$ \\
\hline Colobus polykomos & Leaves, seeds & $\begin{array}{l}\text { Mac Key 1978: Rose 1978; Baranga 1983; Dasilva } \\
\text { 1994; Rowe 1996; Daegling \& Mcgraw 2001 }\end{array}$ \\
\hline Lophocebus albigena & $\begin{array}{l}\text { Fruits }(59 \%) \text {, seeds, leaves }(5 \%) \text {, } \\
\text { flowers }(3 \%) \text {, animal prey } \\
\text { including reptiles and insects }\end{array}$ & Chalmers 1968; Rowe 1996; Lambert 2005 \\
\hline Macaca fascicularis & $\begin{array}{l}\text { Fruits }(64 \%) \text {, seeds, buds, leaves, } \\
\text { animal prey }\end{array}$ & Richard et al. 1989; Rowe 1996 \\
\hline Nasalis larvatus & $\begin{array}{l}\text { Leaves }(44 \%) \text {, seeds }(20 \%) \text {, } \\
\text { fruits }(17 \%) \text {, flowers }(3 \%) \text {, animal prey }\end{array}$ & Yeager \& Kool 1994; Rowe 1996 \\
\hline Papio anubis & $\begin{array}{l}\text { Fruits, seeds, tubers, roots, leaves, } \\
\text { flowers, animal prey }\end{array}$ & Nagel 1973; Rowe 1996 \\
\hline Papio cynocephalus & $\begin{array}{l}\text { Fruits, seeds, leaves, flowers, } \\
\text { tubers, roots, animal prey }\end{array}$ & $\begin{array}{l}\text { Hausfater \& Maccuskey 1980; Rhine et al. 1986, } \\
\text { Norton et al. 1987; Rowe } 1996\end{array}$ \\
\hline Papio hamadryas & $\begin{array}{l}\text { Grass seeds, roots, tubers, } \\
\text { leaves, animal prey }\end{array}$ & Nagel 1973; Rowe 1996 \\
\hline Theropithecus gelada & $\begin{array}{l}\text { Grasses }(90 \%) \text {, seeds, leaves, } \\
\text { animal prey }\end{array}$ & Kawai 1979; Iwamoto 1993; Rowe 1996 \\
\hline
\end{tabular}

seum of Palaeontology and Geology (Greece), and the University of Thessaloniki (Greece). The richest sample comes from Pikermi (Appendix 1) including the typical Mesopithecus pentelicus Wagner, 1839 and dated to the uppermost middle Turolian, MN 12 at -7.0 Ma (Koufos 2006a and reference therein). The RZO sample includes $M$. delsoni Bonis, Bouvrain, Geraads \& Koufos, 1990 and it is dated to early Turolian at $-8.2 \mathrm{Ma}$ (Bonis et al. 1990; Koufos 2006a). Two other middle Turolian Greek localities VTK and PER include Mesopithecus. This form has intermediate characters and dimensions between $M$. delsoni and $M$. pentelicus and it is referred to as $M$. delsoni/pentelicus (Bonis et al. 1997; Koufos 2006b). The locality VTK is dated to the lowermost middle Turolian, MN 12 at $-7.5 \mathrm{Ma}$, while the locality PER to middle Turolian from 7.3-7.1 Ma (Koufos 2006a, Koufos et al. 2006b). The Bulgarian material of Mesopithecus comes from the locality of Hadjidimovo-1 dated to the middle Turolian MN 12; it is determined to M. delsoni/pentelicus (Koufos et al. 2003; Koufos 2009, this volume). The Kalimantsi sample includes several specimens which belong to M. pentelicus; the material comes from the upper levels of Kalimantsi dated to the middle Turolian MN 12 (Koufos et al. 2003).
A set of 162 wild-shot adult specimens representing nine present-day species of cercopithecid (including cercopithecine and colobine) with known differences in diet is here used for comparisons (Table 1; Appendix 2). These extant species were selected because they cover a large spectrum of dietary habits, from leaf-eaters like Nasalis larvatus (Wurmb, 1787) to fruit/seed eaters like Lophocebus albigena (Gray, 1850), to grass-eater Theropithecus gelada (Rüppell, 1835). Table 1 summarizes feeding habits for these extant species.

\section{METHODS}

High-resolution epoxy resin replicas of the upper and lower second molars for extant species were made following traditional methods (Ungar 1996). Because fossil material is scarce, the fossil samples are enlarged in including the first and third with second molars. Such samples including all molars should be then considered with caution. Also, no accurate intra-population (sexual differences) studies can be conducted. Regarding dental microwear analyses, many protocols from casting steps to quantification were employed (for a review, see 
TABLE 2. - Descriptive statistics on extant cercopithecids and populations of Mesopithecus Wagner 1839. Abbreviations: Ls, length of scratch $(\mu \mathrm{m}) ; \mathbf{m}$, mean; $\mathbf{N}$, number of individuals; Nws, number of wide scratches; Nip, number of large pits; Nfs, number of fine scratches; Nsp, number of small pits; Pp, percentage of pits; sem, standard error of the mean.

\begin{tabular}{|c|c|c|c|c|c|c|c|c|c|c|c|c|c|}
\hline & \multirow[b]{2}{*}{$\mathbf{N}$} & \multicolumn{2}{|c|}{ Ls ( $\mu \mathrm{m})$} & \multicolumn{2}{|c|}{ Nws } & \multicolumn{2}{|c|}{ NIp } & \multicolumn{2}{|c|}{ Nfs } & \multicolumn{2}{|c|}{ Nsp } & \multicolumn{2}{|c|}{$\mathrm{Pp}(\%)$} \\
\hline & & $\mathbf{m}$ & sem & m & sem & $\mathbf{m}$ & sem & $\mathbf{m}$ & sem & $\mathbf{m}$ & sem & $\mathbf{m}$ & sem \\
\hline $\begin{array}{c}\text { Chlorocebus } \\
\text { aethiops }\end{array}$ & 16 & 95.9 & 3.7 & 1.8 & 0.4 & 4.9 & 0.7 & 31.8 & 2.4 & 41.2 & 3.7 & 56.8 & 2.9 \\
\hline Colobus polykomos & 21 & 131.7 & 5.9 & 1.7 & 0.3 & 4.5 & 0.5 & 20.0 & 1.6 & 35.5 & 3.0 & 63.3 & 2.9 \\
\hline $\begin{array}{l}\text { Lophocebus } \\
\text { albigena }\end{array}$ & 25 & 99.0 & 3.4 & 1.8 & 0.4 & 9.1 & 0.7 & 32.2 & 1.7 & 47.6 & 3.2 & 61.7 & 2.1 \\
\hline $\begin{array}{l}\text { Macaca } \\
\quad \text { fascicularis }\end{array}$ & 20 & 88.4 & 2.4 & 0.9 & 0.2 & 6.5 & 0.7 & 37.6 & 2.6 & 50.6 & 2.7 & 59.8 & 1.9 \\
\hline $\begin{array}{l}\text { Nasalis } \\
\quad \text { larvatus }\end{array}$ & 15 & 141.2 & 8.8 & 0.4 & 0.2 & 3.8 & 1.0 & 21.7 & 2.2 & 25.9 & 3.1 & 57.0 & 3.0 \\
\hline Papio anubis & 27 & 102.6 & 3.9 & 1.7 & 0.3 & 11.2 & 1.0 & 24.7 & 1.7 & 41.5 & 4.0 & 65.0 & 1.9 \\
\hline P. cynocephalus & 20 & 111.0 & 7.0 & 1.6 & 0.3 & 7.3 & 0.8 & 25.5 & 1.4 & 40.8 & 3.8 & 62.1 & 2.5 \\
\hline P. hamadryas & 9 & 102.5 & 9.7 & 1.6 & 0.6 & 7.8 & 1.5 & 28.0 & 2.1 & 43.3 & 7.2 & 61.4 & 2.5 \\
\hline $\begin{array}{l}\text { Theropithecus } \\
\text { gelada }\end{array}$ & 9 & 123.2 & 13.1 & 1.2 & 0.4 & 4.0 & 1.0 & 21.6 & 2.4 & 8.7 & 1.8 & 33.6 & 3.4 \\
\hline $\begin{array}{l}\text { Mesopithecus } \\
\text { delsoni }\end{array}$ & 3 & 83.0 & 7.0 & 0.7 & 0.3 & 8.7 & 2.2 & 26.7 & 3.2 & 43.0 & 7.5 & 64.4 & 7.2 \\
\hline $\mathrm{RZO}$ & 3 & 83.0 & 7.0 & 0.7 & 0.3 & 8.7 & 2.2 & 26.7 & 3.2 & 43.0 & 7.5 & 64.4 & 7.2 \\
\hline $\begin{array}{l}\text { M. delsoni/ } \\
\text { pentelicus }\end{array}$ & 13 & 98.9 & 3.4 & 1.2 & 0.3 & 6.5 & 0.8 & 31.8 & 2.6 & 40.5 & 4.6 & 57.8 & 3.6 \\
\hline $\mathrm{HD}$ & 6 & 105.6 & 4.9 & 1.5 & 0.5 & 6.8 & 1.3 & 29.2 & 4.3 & 40.2 & 7.1 & 59.4 & 6.0 \\
\hline PER & 4 & 91.4 & 3.9 & 0.8 & 0.5 & 6.5 & 1.9 & 36.8 & 4.8 & 42.5 & 11.8 & 54.7 & 8.3 \\
\hline VTK & 3 & 95.5 & 7.8 & 1.2 & 0.4 & 5.7 & 0.7 & 30.3 & 4.1 & 38.7 & 2.4 & 58.8 & 3.6 \\
\hline M. pentelicus & 41 & 110.3 & 4.1 & 1.4 & 0.2 & 5.4 & 0.4 & 28.3 & 1.4 & 40.4 & 2.4 & 59.7 & 1.8 \\
\hline PIK & 30 & 113.8 & 5.0 & 1.5 & 0.2 & 5.3 & 0.5 & 27.5 & 1.6 & 39.7 & 2.9 & 59.5 & 2.2 \\
\hline $\mathrm{K}$ & 11 & 100.8 & 6.2 & 1.1 & 0.4 & 5.8 & 0.9 & 30.6 & 3.0 & 42.4 & 4.1 & 60.1 & 3.0 \\
\hline
\end{tabular}

Ungar et al. 2008). The protocol of Merceron et al. $(2005 \mathrm{~b})$ is here considered (see also Merceron $e t$ al. 2004, 2007). Data were collected on the dental facet 9 , located on the lingual protocone facet for upper molars and on the buccal hypoconid facet for the lower molars (Kay \& Hiiemae 1974; Maier 1977). All microwear scars crossing a $0.09 \mathrm{~mm}^{2}$ $(300 \times 300 \mu \mathrm{m})$ area using Optimas v. 6.2 image analysis software (Media Cybernetics) are quantified. The pits are clearly distinguishable from scratches; however, the distinction between elongated pits and short wide scratches may be unreliable. Microwear scars are then defined as pits or scratches as follows: pits have a width to length ratio greater than $1 / 4$, and scratches have a lower ratio (Grine 1986). Using Optimas v. 6.2, the pits are marked with a dot and the scratches with a line which is automatically measured as the "length of scratch" (Ls). After counting the number of pits $(\mathrm{Np})$ and the number of scratches (Ns), the microwear scars are assigned to a category depending on their size (length of major axis for pits and width for scratches). Subsequently, the numbers of wide scratches (Nws; width $>15 \mu \mathrm{m}$ ), fine scratches (Nfs; width $<15 \mu \mathrm{m}$ ), large pits (Nlp; major axis $>15 \mu \mathrm{m}$ ), and small pits (Nsp; major axis $<15 \mu \mathrm{m}$ ) are determined. The percentage of pits $\left(\mathrm{Pp}=100^{*} \mathrm{~Np} /\right.$ $[\mathrm{Np}+\mathrm{Ns}]$ ) is then computed (Table 2).

The data is here investigated through the combination of a Principal Component Analysis (PCA hereafter) and analyses of variance. The PCA framework is built with extant specimens and raw data. Then, fossil specimens are inserted as supplementary data and therefore do not interfere with the model. The PCA generates six independent new variables based on the six initial variables of microwear pattern: $\mathrm{Nfs}$, Nsp, Nlp, Nws, Ls and Pp (Tables 3; 4). In order to support interpretations, the inter- and intra-specific 
TABLE 3. - Results of principal component analysis of dental microwear pattern of nine extant species of cercopithecid. Eigenvalue and percentage of the total variance for each component.

\begin{tabular}{ccc}
\hline Component & Eigenvalues & \% Total variance \\
\hline 1 & 2.31 & 38.53 \\
2 & 1.37 & 22.77 \\
3 & 1.02 & 17.01 \\
4 & 0.72 & 12.01 \\
5 & 0.51 & 8.51 \\
6 & 0.07 & 1.18 \\
\hline
\end{tabular}

differences in distribution along the new computed variables (components) are tested through analyses of variance (Tables 5; 6). The sources of variation are then determined by the combination of a Tukey's Honest Significant Differences test with a Fischer's Least Significant Differences test; the latter being less conservative than the former (Table 7). A rank transformation is conducted before each set of analyses to avoid violations of parametric test assumptions (Conover \& Iman 1980; Sokal \& Rohlf 1998).

\section{RESULTS}

The graphic distribution of the extant and extinct cercopithecids through PCA is given in Figure 1. Along the first component $(38.53 \%$ of the total variance), the distribution of the specimens is mainly controlled by the positive weight of the variable Ls (length of scratch) and the negative ones of Nsp, Nlp, and Pp (number of small pits, number of large pits, percentage of pits, respectively, Fig. 1; Tables 3; 4). The variable Nfs (number of fine scratches, and the couple Pp (percentage of pits) and Ls (length of scratch) in a lesser extent, contribute to the spread of the extant specimens along the second component $(22.77 \%$ of the total variance; Fig. 1; Tables 3; 4). The spread of specimens along the third component ( $17.01 \%$ of the total variance) is controlled by the variable Nws (number of wide scratches, Tables 3; 4). According to the Kaiser' criterion, the drop in percentage of the total variance expressed from the third to the next eigenvalues allow us to disregard coordinates from the fourth component (Tables 3; 4) (Kaiser 1960).

\section{EXTANT SPECIES}

Along the first component, there is a trend from Theropithecus gelada, a grass-eater, to extant colobines (Nasalis larvatus and Colobus polykomos (Zimmermann, 1780)) highly involved in folivory, up to a cluster of cercopithecids with low coordinates (Fig. 1). The latter taxa display various feeding habits including leaves, fruits, seeds, and even underground vegetal parts. These differences in the distribution of the specimens are significantly supported (Tables 5-7) and are due to the variation of the variables Nsp, Nlp, Pp, and Ls (Tables 2; 7; Fig. 2). Along the second component there is a trend from the two colobines $(N$. larvatus and C. polykomos) to Macaca fascicularis (Raffles, 1821); the former ones have fewer fine scratches than the cercopithecid (Tables 2; 7; Fig. 2A-D). This differential spread between extant species along the second axis is significantly supported (Tables 5-7; Fig. 1). As mentioned above, the spread along the third component is mainly controlled by the variable Nws. This variable displays high variability for most of the species (Table 2), resulting in very few significant differences between species. In fact, $N$. larvatus is the only taxon which significantly differs from others.

\section{MESOPITHECUS VERSUS EXTANT SPECIES}

The three Mesopithecus samples (M. delsoni, $M$. delsoni/pentelicus, and $M$. pentelicus) plot far from T. gelada and their two extant relatives, $N$. larvatus and C. polykomos (Tables 2; 7; Fig. 1). Such distribution is due to a heavy pitting (Table 2; Fig. 2). Indeed, the distribution of the Mesopithecus samples through the PCA supports affinities with cercopithecids involved in frugivory, in seed predation or in a generalist diet. It should also be noted here that no significant difference is detected between the Mesopithecus samples on one hand and Chlorocebus aethiops (Linnaeus, 1758) and Papio hamadryas (Linnaeus, 1758) on the other hand. Chlorocebus aethiops is a semi-terrestrial cercopithecine foraging on fruits, leaves, seeds and animal prey (Nakawaga 2003; Rowe 1996 and citations therein). The second is a terrestrial monkey consuming various items from the ground such as grass and tubers. 
TABLE 4. - Results of principal components analysis of dental microwear pattern of nine extant species of cercopithecid. Communities $r$ and square communities $r^{2}$ between variables and axis. Abbreviations: see text.

\begin{tabular}{|c|c|c|c|c|c|c|c|c|c|c|c|c|}
\hline \multirow{2}{*}{$\begin{array}{l}\text { Component } \\
\text { Variables }\end{array}$} & \multicolumn{2}{|c|}{1} & \multicolumn{2}{|c|}{2} & \multicolumn{2}{|c|}{3} & \multicolumn{2}{|c|}{4} & \multicolumn{2}{|c|}{5} & \multicolumn{2}{|c|}{6} \\
\hline & $r$ & $r^{2}$ & $r$ & $r^{2}$ & $r$ & $r^{2}$ & $r$ & $r^{2}$ & $r$ & $r^{2}$ & $r$ & $r^{2}$ \\
\hline Ls & 0.676 & 0.458 & 0.443 & 0.196 & -0.120 & 0.014 & 0.119 & 0.014 & -0.564 & 0.318 & 0.013 & 0.000 \\
\hline ws & .085 & 0.007 & -0.091 & 008 & -0.973 & 0.9 & 0.150 & 0.022 & 0.123 & 0.015 & 0.012 & 0.000 \\
\hline NIp & -0.644 & 0.415 & 0.105 & 0.011 & -0.242 & 0.059 & -0.682 & 0.465 & -0.222 & 0.049 & -0.030 & 0.001 \\
\hline $\mathrm{Pp}$ & -0.804 & 0.647 & 0.531 & 0.282 & 0.007 & 0.000 & 0.197 & 0.039 & 0.003 & 0.000 & 0.180 & 0.033 \\
\hline Nfs & -0.175 & 0.031 & -0.931 & 0.867 & 0.016 & 0.000 & 0.057 & 0.003 & -0.294 & 0.086 & 0.112 & 0.013 \\
\hline Nsp & -0.869 & 0.755 & -0.045 & 0.002 & -0.018 & 0.000 & 0.420 & 0.176 & -0.205 & 0.042 & -0.156 & 0.024 \\
\hline
\end{tabular}

TABLE 5. - Results of inter-specific (including extant and extinct cercopithecoids) analyses of variance. Coordinates were ranktransformed before running analysis.

\begin{tabular}{|c|c|c|c|c|c|c|c|c|c|c|c|c|c|}
\hline & \multirow[b]{2}{*}{ df } & \multicolumn{4}{|c|}{ Component 1} & \multicolumn{4}{|c|}{ Component 2} & \multicolumn{4}{|c|}{ Component 3} \\
\hline & & ss & MS & $\mathbf{F}$ & $\mathbf{p}$ & ss & MS & $\mathbf{F}$ & $\mathbf{p}$ & ss & MS & $\mathbf{F}$ & $\mathbf{p}$ \\
\hline Effect & 11 & 237698 & 21609 & 7.0158 & $<0.001$ & 212867 & 19352 & 6.0473 & $<0.001$ & 88941 & 8086 & 2.1285 & 0.019 \\
\hline Error & 207 & 637572 & 3080 & & & 662403 & 3200 & & & 786329 & 3799 & & \\
\hline Total & 218 & 875270 & & & & 875270 & & & & 875270 & & & \\
\hline
\end{tabular}

TABLE 6. - Results of intra-specific analyses of variance. Intra-specific differences are investigated for M. pentelicus between the populations from Pikermi and Kalimantsi. Coordinates were rank-transformed before running analysis.

\begin{tabular}{|c|c|c|c|c|c|c|c|c|c|c|c|c|c|}
\hline & \multirow[b]{2}{*}{ df } & \multicolumn{4}{|c|}{ Component 1} & \multicolumn{4}{|c|}{ Component 2} & \multicolumn{4}{|c|}{ Component 3} \\
\hline & & SS & MS & $\mathbf{F}$ & $p$ & SS & MS & $\mathbf{F}$ & p & ss & MS & $\mathbf{F}$ & $\mathbf{p}$ \\
\hline $\begin{array}{l}\text { Effect } \\
\text { Error } \\
\text { Total }\end{array}$ & $\begin{array}{c}1 \\
39 \\
40\end{array}$ & $\begin{array}{r}161.02 \\
5578.98 \\
5740.00\end{array}$ & $\begin{array}{l}161.02 \\
143.05\end{array}$ & 1.1256 & 0.295 & $\begin{array}{r}127.22 \\
5612.78 \\
5740.00\end{array}$ & $\begin{array}{l}127.22 \\
143.92\end{array}$ & 0.8840 & 0.353 & $\begin{array}{r}127.22 \\
5612.78 \\
5740.00\end{array}$ & $\begin{array}{l}127.22 \\
143.92\end{array}$ & 0.8840 & 0.353 \\
\hline
\end{tabular}

\section{MESOPITHECUS VERSUS MESOPITHECUS}

There is no significant difference between the distributions of the three Mesopithecus samples. This likely supports similar feeding habits between these three forms (Tables 2; 5-7; Fig. 2). The intra-specific analysis does not detect any significant difference between the two samples of M. pentelicus (Bulgaria versus Pikermi; Tables 2; 5; 6).

\section{DISCUSSION}

The paleobiology of Mesopithecus is still under debate. As mentioned above, the colobines are highly involved in folivory. Even in the case of Semnopithecus, a terrestrial colobine, leaves con- tribute more than $70 \%$ to its diet (Dela 2007; Sayers \& Norconk 2008). So, with the exception of the latter species, most of the modern colobines are arboreal forest dwellers (Rowe 1996). Mesopithecus postcrania do not support an arboreal mode of locomotion. In fact, the calcaneal morphology of Mesopithecus would indicate a semi-terrestrial mode of locomotion (Youlatos 2003). However, the distal part of the hindlimb does not seem to be so discriminating since a recent thorough analysis concludes that depending on statistical protocols, the metric data of the calcaneum may depict Mesopithecus as an arboreal monkey as well (Escarguel 2005). Anyway, the postcranial morphology and proportions in comparison to the extant cercopithecids indicate at least a semi-terrestrial mode of 

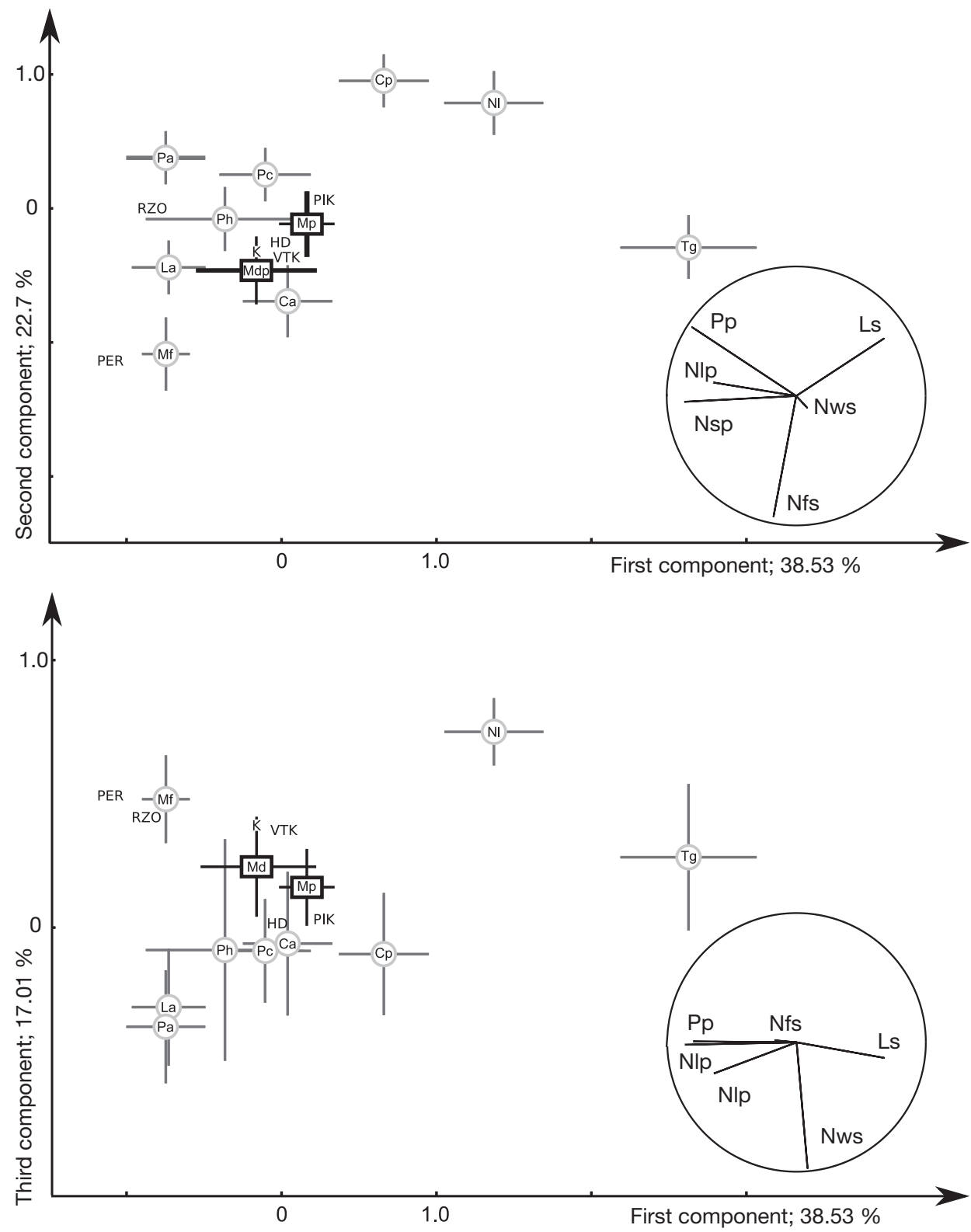

FIG.1. - Distribution (mean and standard error of the mean) of extant and extinct cercopithecids along the first and second components of the Principal Component Analysis. The specimens of Mesopithecus Wagner, 1839 are included as supplementary data. Extant species: Ca, Chlorocebus aethiops (Linnaeus, 1758); Cp, Colobus polykomos (Zimmermann, 1780); La, Lophocebus albigena (Gray, 1850); Mf, Macaca fascicularis (Raffles, 1821); NI, Nasalis larvatus (Wurmb, 1787); Pa, Papio anubis (Lesson, 1827); Pc, Papio cynocephalus (Linnaeus, 1766); Ph, Papio hamadryas (Linnaeus, 1758); Tg, Theropithecus gelada (Rüppell, 1835). Fossil specimens are plotted according to where they were unearthed: HD, Hadjidimovo 1 (Bulgaria); K, Kalimantsi (Bulgaria); PER, Perivolaki (Greece); PIK, Pikermi (Greece); RZO, Ravin des Zouaves 5 (Greece); VTK, Vathylakkos 2 (Greece). Also, all specimens belonging to M. delsoni/ pentelicus or to M. pentelicus Wagner, 1839 symbolized as Mdp and Mp, respectively. 
TABLE 7. - Results on pairwise comparisons. Significance at $a<0.05$ is indicated in normal font for the Fisher's Least Significant Difference test and in bold font for both Tukey's Honest Significant Difference and Fisher's Least Significant Difference tests. Abbreviations along the first line refer to the initials of the genera and species mentioned on the first raw.

\begin{tabular}{|c|c|c|c|c|c|c|c|c|c|c|c|}
\hline & M. d & M. dp & M. p & Ch. a & C. $p$ & L. $a$ & M. $f$ & N. I & P. a & P.c & P.h T.g \\
\hline \multicolumn{12}{|l|}{ M. delsoni } \\
\hline \multicolumn{12}{|l|}{$\begin{array}{l}\text { M. delsoni/ } \\
\text { pentelicus }\end{array}$} \\
\hline \multicolumn{12}{|l|}{ M. pentelicus } \\
\hline \multicolumn{12}{|l|}{ C. aethiops } \\
\hline C. polykomos & $\mathrm{C} 1$ & C2 & $\mathrm{C} 2$ & $\mathrm{C2}$ & & & & & & & \\
\hline L. albigena & & $\mathrm{C} 1$ & $\mathrm{C} 1$ & $\mathrm{C} 1$ & C1, C2 & & & & & & \\
\hline M. fascicularis & & $\mathrm{C} 1$ & $\mathrm{C} 1, \mathrm{C} 2$ & $\mathrm{C} 1$ & $\mathrm{C}_{1}, \mathrm{C}_{2}$ & C3 & & & & & \\
\hline N. larvatus & C1 & $\mathrm{C} 1, \mathrm{C} 2$ & $\begin{array}{l}\text { C1, C2, } \\
\text { C3 }\end{array}$ & $\begin{array}{l}\text { C1, C2, } \\
\text { C3 }\end{array}$ & $\mathrm{C} 3$ & $\begin{array}{l}\text { C1, C2, } \\
\text { C3 }\end{array}$ & $\mathrm{C}_{1}, \mathrm{C}_{2}$ & & & & \\
\hline P. hanubis & & $\mathrm{C} 2$ & $\mathrm{C} 1$ & $\mathrm{C} 1, \mathrm{C} 2$ & C1 & $\mathrm{C} 2$ & C2, C3 & C1, C3 & & & \\
\hline P. cynocephalus & & $\mathrm{C} 2$ & & $\mathrm{C} 2$ & $\mathrm{C} 2$ & $\mathrm{C} 2$ & C2, C3 & C1, C3 & & & \\
\hline P. hamadryas & & & & & $\mathrm{C} 2$ & & $\mathrm{C} 2$ & $\begin{array}{l}\text { C1, C2, } \\
\text { C3 }\end{array}$ & & & \\
\hline T. gelada & C1 & C1 & C1 & C1 & $\mathrm{C} 1, \mathrm{C} 2$ & C1 & C1 & C2 & $\mathrm{C}_{1}, \mathrm{C}_{2}$ & C1 & C1 \\
\hline
\end{tabular}

locomotion (Gabis 1961; Szalay \& Delson 1979; Zapfe 1991; Delson 1994; Koufos et al. 2003). Mesopithecus had therefore the opportunity to forage on trees and ground.

The presence of semi-terrestrial monkeys in Eastern Europe during Turolian agrees with the paleoenvironmental data. The carbon isotope signature in tooth enamel of herbivorous mammals excludes the presence of $\mathrm{C} 4$ grasslands in the Eastern Mediterranean (Bocherens et al. 1994; Quade et al. 1994, 1995; Zazzo et al. 2002; Merceron et al. 2006) whereas faunal analyses undoubtedly exclude closed-forested ecosystems (Bonis et al. 1992, 1999; Fortelius \& Solounias 2000; Eronen \& Rook 2004; Koufos 2006a, 2009, this volume; Koufos et al. 2006a, 2008; Spassov et al. 2006). The microwear analyses on the ungulates from several investigated localities of the Eastern Mediterranean point out a large spectrum of dietary habits from browse to graze amongst ruminants and equids. These studies suggest the existence of open areas displaying a rich herbaceous vegetal layer including graminoids and patches of trees and/or bushes (Solounias et al. 1999; Merceron et al. 2005a, 2006; Koufos et al. 2006a, 2008). Based on phytolith assemblages, the presence of $\mathrm{C} 3$ graminoids is attested in the region (Strömberg et al. 2007) thus restraining interpretations from isotope analyses (Bocherens et al. 1994; Quade et al. 1994) which linked the lack of C4 plants to the dominance of forested habitats. Although the different environmental indicators are in accordance with the locomotion mode of Mesopithecus, they cannot conclude on its feeding preferences since fruit-dominated and leaf-dominated primates may share the same environment exploiting different ecological niches (Rowe 1996).

As Benefit (2000) reports, the bilophodonty of the earliest cercopithecoids was initially wrongly interpreted as an adaptation to a leaf-dominated diet. Since then, bilophodonty has been interpreted as a response to the need for a more efficient grinding mechanism to chew fruits (Lambert et al. 2004). Benefit (2000) also supports the last hypothesis since the shearing molar crests of Mesopithecus are lower than in the extant colobines suggesting a diet rich in fruits. Based on the present results, the feeding habits of the "three" Mesopithecus are alike. They cannot be depicted as leaf-eaters. Seeds, 

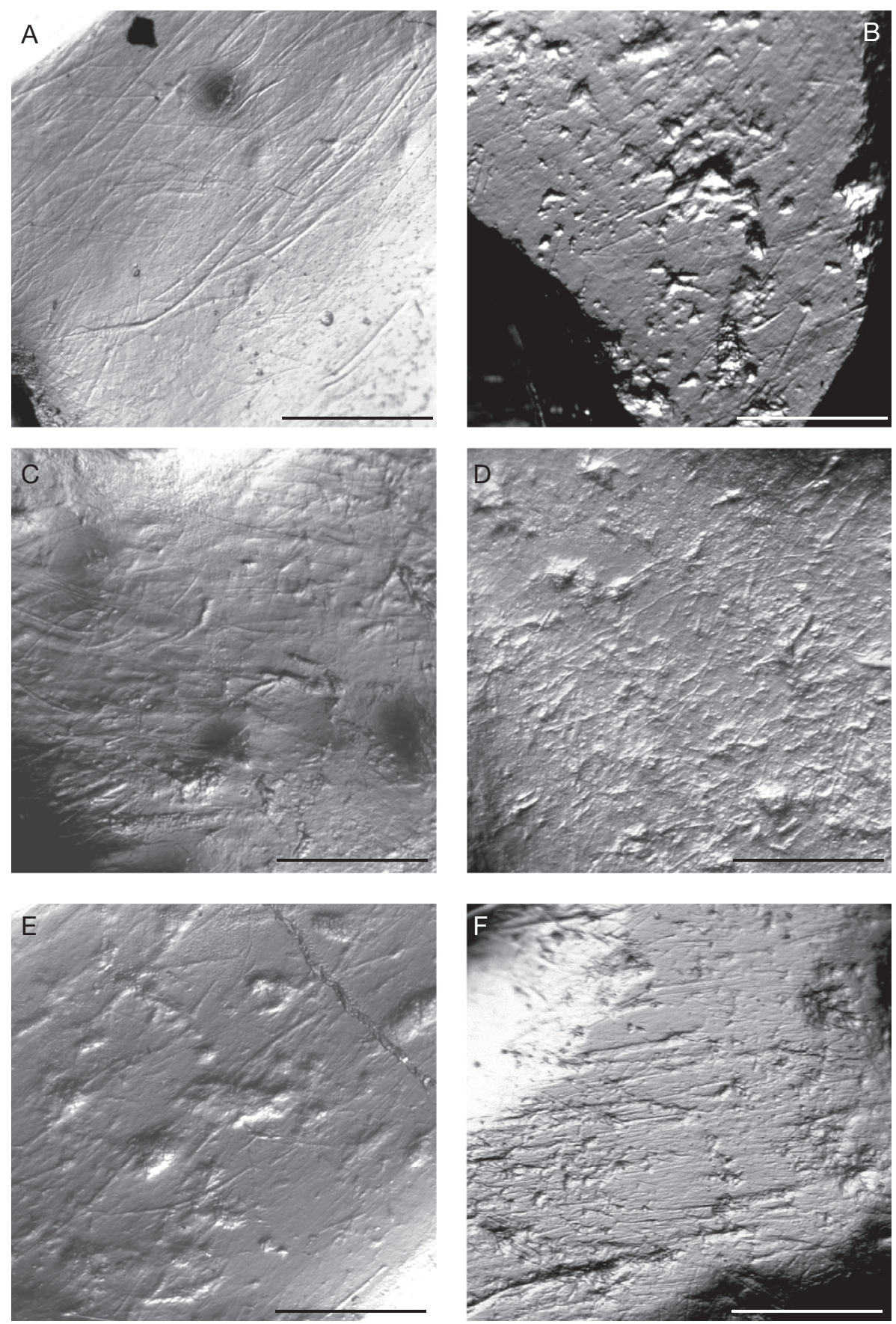

FIG. 2. - Dental facets nine of second molars for extant and extinct cercopithecids displaying dental microwear scars: A, Nasalis larvatus (Wurmb, 1787) (ZSM-1907-4023); B, Lophocebus albigena (Gray, 1850) (RMCA-83-006-0276); C, Chlorocebus aethiops (Linnaeus, 1758) (MNHN-CG-1972-309); D, Papio hamadryas hamadryas Linnaeus, 1758 (SNG-15831); E, Mesopithecus delsoni/ pentelicus (HD-340); F, M. pentelicus (NHMW-1998z77-14). Scale bars: $300 \mu \mathrm{m}$. 
fruits or even underground vegetal parts were some of the main components in their diet. However, the ingestion of such hard/brittle or tough items does not exclude soft fruits and foliage in their diet since the cercopithecoid-like molars display two functionalities: high crests acting as blades for shearing and lophs as wedges to break hard items (Lucas \& Teaford 1994).

Both mode of locomotion and feeding habits of Mesopithecus are in agreement with its wide dispersion in Western Eurasia (with the exception of Anatolia and Iberic peninsula) suggesting opportunistic feeding habits. Most of the extant colobine taxa are restricted to forested habitats and to folivory whereas Mesopithecus was widely dispersed in different provinces with various environmental and climatic conditions. As mentioned above, Mesopithecus ( $M$. delsoni, $M$. delsoni/pentelicus, and $M$. pentelicus) probably had feeding preferences similar to $C$. aethiops and P. hamadryas. Actually, considering the post-cranial anatomy and the mode of locomotion, the similarities are greater with $C$. aethiops. Another similarity between this modern monkey and Mesopithecus is their wide range of geographic distribution. In fact, the vervet monkey occupies a large spectrum of habitats (swamps, riverine forests, savanna woodlands or even scrublands merging the dry Sahel) from Senegal to South Africa and feeds on fruits, seeds, and leaves (Rowe 1996).

\section{Acknowledgements}

It was a great pleasure for us to prepare the present article for this special edition of the Geodiversitas to the honour of Prof. Louis de Bonis and George D. Koufos. First of all, we thank the colleagues who have excavated in Greece since 1972 with Louis de Bonis. G. Merceron is grateful to the following heads and curators for giving access to the collections: M. Robineau, J. Cuisin, and C. Sagne (MNHN, Paris), O. Röhrer-Ertl (Zoologische Staatssammlung of Munich), G. Storch and J. Anger (Naturmuseum Senckenberg, Frankfurt), W. Van Neer and W. Wendelen (Musée Royal d'Afrique Centrale, Tervuren), U. B. Göhlich (Naturhistorisches Museum in Wien), to D. Nagel (Wien Universität), D. Kovatchev (NHM, Assenovgrad) and N. Spassov
(NHM, Sofia). G. D. Koufos thanks M. Dermitzakis from the University of Athens for giving us access to the material at his disposal and to Dr S. Roussiakis for his great help.

This study was funded by the Singer-Polignac Foundation, and by the EEDEN program (ESF) to G.M. Finally, we are grateful to A. Ramdarshan for the English improvement and to A. Ohler, G. Semprebon and E. Schulz for their comments which improve the quality of this manuscript.

\section{REFERENCES}

Agustí J., Sanz de Siria A. \& Garcés M. 2003. Explaining the end of the hominoid experiment in Europe. Journal of Human Evolution 45: 145-153.

ANDrews P., HARrison T., DElSON E., BERNOR R. L. \& MARTIN L. 1996. — Distribution and biochronology of European and southwest Asian Miocene catarrhines, in Bernor R. L., Fahlbusch V. \& Mittman H. W. (ed.), The Evolution of Western Eurasian Neogene Mammal Faunas. Columbia University Press, New York: 168-207.

BARANGA D. 1983. - Changes in chemical composition of food parts in the diet of Colobus monkeys. Ecology 64: 668-673.

BENEFIT B. R. 2000. — Old World monkey origins and diversification: an evolutionary study of diet and dentition, in WhiteHEAD P. F. \& Jolly C. J. (eds), Old World monkeys. Cambridge University Press, Cambridge: 133-179.

Benefit B. R. \& PickFord M. 1986. - Miocene fossil cercopithecoids from Kenya. American Journal of Physical Anthropology 69: 441-464.

Bocherens H., Fizet M., Mariotti A., Bellon G. \& BOREL J. P. 1994. — Les gisements de mammifères du Miocène supérieur de Kemiklitepe, Turquie: 10. Biogéochimie isotopique. Bulletin du Muséum national d'Histoire naturelle, Paris, 4e série, 16: 211-223.

Bonis L. De, Bouvrain G. \& Koufos G. D. 1999. Palaeoenvironments of late Miocene primate localities in Macedonia, in Agustí J., RoOK L. \& ANDREWS P. (eds), Hominoid Evolution and Climatic Change in Europe: The Evolution of Neogene Terrestrial Ecosystems in Europe. Cambridge University Press, Cambridge: 413-435.

Bonis L. DE, Bouvrain G., Geraads D. \& Koufos G. D. 1990. - New remains of Mesopithecus (Primates, Cercopithecoidea) from the late Miocene of Macedonia (Greece), with the description of new species. Journal of Vertebrate Paleontology 10: 473-483.

Bonis L. DE, Bouvrain G., Geraads D. \& Koufos 
G. D. 1992. — Diversity and paleoecology of Greek late Miocene mammalian faunas. Palaeogeography, Palaeoclimatology, Palaeoecology 91: 99-121.

Bonis L. De, Bouvrain G., GeraAds D. \& Koufos G. D. 1997. - New material of Mesopithecus (Mammalia, Cercopithecidae) from the late Miocene of Macedonia, Greece. Neues Jahrebuch für Geologie und Paläontologie, H. 5.: 265-275.

Chalmers N. R. 1968. - Group composition, ecology and daily activities of free living mangabeys in Uganda. Folia Primatologia 8: 247-262.

Chivers D. J. 1994. - Functional anatomy of the gastrointestinal tract, in DAVIES A. G. \& OATES J. F. (eds), Colobine monkeys. Their Ecology, Behaviour, and Evolution. Cambridge University Press, Cambridge: 205-227.

Conover V. J. \& IMAn R. L. 1980. — The rank transformation as a method of discrimination with some examples. Communication of Statistics, Part A, Theory and Methods 9: 465-487.

Daegling D. J. \& McGraW W. S. 2001. - Feeding, diet, and jaw form in West African Colobus and Procolobus. International Journal of Primatology 22: 1033-1055.

Dasilva G. L. 1994. - Diet of Colobus polykomos on Tiwai island: selection of food in relation to its seasonal abundance and nutritional quality. International Journal of Primatology 15: 655-680.

DELA J. S. D. 2007. - Seasonal food use strategies of Semnopithecus vetulus nestor, at Panadura and Piliyandala, Sri Lanka. International Journal of Primatology 28: 607-626.

DELSON E. 1994. - Evolutionary history of the colobine monkeys in paleoenvironmental perspective, in DAVIES A. G. \& OATES J. F. (eds), Colobine Monkeys. Their Ecology, Behaviour, and Evolution. Cambridge University Press, Cambridge: 11-43.

Eronen J. T. \& RoOK L. 2004. - The Mio-Pliocene European primate fossil record: dynamics and habitat tracking. Journal of Human Evolution 47: 323-341.

EsCARGUEL G. 2005. - Mathematics and the lifeway of Mesopithecus. International Journal of Primatology 26: 801-823.

ForTelius M. \& SOlounias N. 2000. - Functional characterization of ungulate molars using the abrasion-attrition wear gradient: a new method for reconstructing paleodiets. American Museum Novitates 3301: 1-36.

GABIS R. 1961. — Les os des membres chez les singes synomorphes. Mammalia 24: 577-602.

GRINE F. E. 1986. — Dental evidence for dietary differences in Australopithecus and Paranthropus: a quantitative analysis of permanent molar microwear. Journal of Human Evolution 15: 783-822.

HARRISON T. \& DELSON E. 2007. - ?Mesopithecus sivalensis from the late Miocene of the Siwaliks.
American Journal of Physical Anthropology, Supplement 44: 162.

Hausfater D. G. \& MacCuskey S. A. 1980. - Feeding behavior of yellow baboons (Papio cynocephalus): relationship to age, gender and dominance rank. Folia Primatologica 34: 170-195.

Heintz E., Brunet M. \& Battail B. 1981. — A cercopithecid primate from the late Miocene of Molayan, Afghanistan, with remarks on Mesopithecus. International Journal of Primatology 2: 273-284.

IwAMOTO T. 1993. - The ecology of Theropithecus gelada, in JABLONSKI N. (ed.), Theropithecus : the Rise and Fall of a Primate Genus. Cambridge University Press, Cambridge: 441-452.

KaISER H. F. 1960. - The application of electronic computers to factor analysis. Educational and Psychological Measurement 20: 141-151.

KAWAI M. 1979. - Ecological and sociobiological studies of Gelada baboons. Contributions to Primatology 16: 1-334.

Kay N. B. K. \& Davies A. G. 1994. - Digestive physiology, in Davies A. G. \& OATES J. F. (eds), Colobine Monkeys. Their Ecology, Behaviour, and Evolution. Cambridge University Press, Cambridge: 229-249.

KaY R. F. \& Hilemae R. K. 1974. - Jaw movement and tooth use in recent and fossil primates. Journal of Human Evolution 40: 227-256.

KoUfos G. D. 2006a. - The Neogene mammal localities of Greece: Faunas, chronology and biostratigraphy. Hellenic Journal of Geosciences 41: 183-214.

Koufos G. D. 2006b. - The late Miocene vertebrate locality of Perivolaki, Thessaly, Greece. 3. Primates. Palaeontographica A, 276: 23-37.

KoufOS G. D. 2006c. - Palaeoecology and chronology of the Vallesian (late Miocene) in the Eastern Mediterranean region. Palaeogeography, Palaeoclimatology, Palaeoecology 234: 127-145.

Koufos G. D. 2009. - The Neogene cercopithecids (Mammalia, Primates) of Greece. Geodiversitas 31 (4): 817-850.

Koufos G. D., Spassov N. \& Kovatchev D. 2003. Study of Mesopithecus (Primates, Cercopithecidae) from the late Miocene of Bulgaria. Palaeontographica A, 269: 39-91.

Koufos G. D., Kostopoulos D. S. \& Merceron G. 2008. - The late Miocene mammal faunas of the Mytilinii Basin, Samos Island, Greece: new collection. 1. Palaeoecology-Palaeobiogeography. Beiträge zur Paläontologie 31: 187-203.

Koufos G. D., Merceron G., Kostopoulos D. S., Vlachou T. D. \& Sylvestrou I. A. 2006a. - The late Miocene vertebrate locality of Perivolaki, Thessaly, Greece. 11. Palaeoecology and Palaeobiogeography. Palaeontographica A, 276: 201-221.

Koufos G. D., Sen S., Kostopoulos D. S., Sylvestrou I. A. \& Vlachou T. D. 2006b. - The late Miocene 
vertebrate locality of Perivolaki, Thessaly, Greece. 10. Chronology. Palaeontographica A, 276: 185-200.

LAMBERT J. E. 1998. - Primate digestion: interactions among anatomy, physiology, and feeding ecology. Evolutionary Anthropology 7: 8-20.

LAMBERT J. E. 2005. - Competition, predation, and the evolutionary significance of the Cercopithecine Cheek Pouch: the case of Cercopithecus and Lophocebus. American Journal of physical Anthropology 126: 183-192.

Lambert J. E., Chapman C. A., Wrangham R. W. \& CONKLIN-BRitTAin N. L. 2004. - Hardness of cercopithecine foods: Implications for the critical function of enamel thickness in exploiting fallback foods. American Journal of Physical Anthropology 125: 363-368.

LuCAS P. W. \& TEAFord M. F. 1994. - Functional morphology of colobine teeth, in DAVIES A. G. \& OATES J. F. (eds), Colobine Monkeys. Their Ecology, Behaviour, and Evolution. Cambridge University Press, Cambridge: 173-203.

MAC KeY D. 1978. — Soils, vegetation and seed eating by black colobus monkeys, in MonTGOMERY G. G. (ed.), The Ecology of Arboreal Folivores. Smithsonian Institution Press, Washington D.C.: 423-437.

MAIER W. 1977. — Die Evolution der bilophodonten molaren der Cercopithecoidea. Zeitschrift für Morphologie und Anthropologie 68: 26-56.

Merceron G., Viriot L. \& Blondel C. 2004. — Tooth microwear pattern in roe deer (Capreolus capreolus, L.) from Chizé (Western France) and relation to food composition. Small Ruminant Research 53: 125-138.

Merceron G., Bonis L. De, Viriot L. \& Blondel C. 2005a. - Dental microwear of the late Miocene bovids of Northern Greece: the Vallesian/Turolian environmental changes as explanation of the disappearance of Ouranopithecus macedoniensis? Bulletin de la Société géologique de France 176: 475-484.

Merceron G., Blondel C., Bonis L. De, Koufos G. D. \& Viriot L. 2005b. - A new dental microwear analysis: application to extant Primates and Ouranopithecus macedoniensis (late Miocene of Greece). Palaios 20: 551-561.

Merceron G., Schulz E., Kordos L. \& Kaiser T. M. 2007. - Paleoenvironment of Dryopithecus brancoi at Rudabánya, Hungary: evidence from dental mesoand micro-wear analyses of large vegetarian mammals. Journal of Human Evolution 53: 331-349.

Merceron G., Zazzo A., Spassov N., Geraads D. \& KovaCHEV D. 2006. - Bovid paleoecology and paleoenvironments from the late Miocene of Bulgaria: evidence from dental microwear and stable isotopes. Palaeogeography, Palaeoclimatology, Palaeoecology 241: 637-654.

NAGEL U. 1973. - A comparison of Anubis baboons, Hamadryas baboons and their hybrids at a species border in Ethiopia. Folia Primatologia, 19: 104-165.

NAKAWAGA N. 2003. - Difference in food selection between patas monkeys (Erythrocebus patas) and tantalus monkeys (Cercopithecus aethiops tantalus) in Kala Maloue National Park, Cameroon, in relation to nutrient content. Primates 44: 3-11.

NeLsOn S. 2003. - The Extinction of Sivapithecus: Faunal and Environmental Changes in the Siwaliks of Pakistan. Brill Academic Press, Boston, $138 \mathrm{p}$.

Norton G. W., Rhine R. J., Wynn G. W. \& Wynn R. D. 1987. - Baboon diet: a five year study of stability and variability in the plant feeding and habitat of the yellow baboons (Papio cynocephalus) of Mikumi National Park, Tanzania. Folia Primatologica 48: 78-120.

Quade J., Solounias N. \& Cerling T. E. 1994. Stable isotopic evidence from paleosol carbonates and fossil teeth in Greece for forest or woodlands over the past 11 Ma. Palaeogeography, Palaeoclimatology, Palaeoecology 108: 41-53.

Quade J., Cerling T. E., Andrews P. \& Alpagut A. 1995. - Paleodietary reconstruction of Miocene faunas from Pasalar, Turkey using stable carbon and oxygen isotopes of fossil tooth enamel. Journal of $\mathrm{Hu}$ man Evolution 28: 373-384.

Rhine R. J., Norton G. W., Wynn G. W., Wynn R. D. \& RHINe H. B. 1986. - Insect and meat eating among infant and adult baboons (Papio cynocephalus) of Mikumi National Park, Tanzania. American Journal of Physical Anthropology 70: 105-118.

RichaRD A. F., GOLDSTEIN S. J. \& DEWAR R. E. 1989. Weed macaques: the evolutionary implications of macaque feeding ecology. International Journal of Primatology 10: 569-594.

Rose M. D. 1978. - Feeding and associated positional behavior of black and white colobus monkeys (Colobus guereza), in Montgomery G. G. (ed.), The Ecology of Arboreal Folivores. Smithsonian Institution Press, Washington D.C.: 253-262.

Rowe N. 1996. - The Pictorial Guide to the Living Primates. Pogonias Press, New York, 263 p.

SAYERS K. \& NorCOnK M. A. 2008. - Himalayan Semnopithecus entellus at Langtang National Park, Nepal: diet, activity patterns, and resources. International Journal of Primatology 29: 509-530.

Semenov Y. 2001. - Stratigraphic distribution of the terrestrial carnivores in the Vallesian and Turolian of Ukraine. Beitrage zur Paläontologie 26: 139-144.

SOKAL R. R. \& ROHLF J. F. 1998. - Biometry: The Principles and Practice of Statistics in Biological Research. Freeman \& Co, New York, 887 p.

Solounias N., Plavcan J. M., Quade J. \& Witmer L. 1999. - The paleoecology of the Pikermian biome and the savanna myth, in Agustí J., ANDREWS P. \& Rook L. (ed.), Evolution of the Neogene Terrestrial Ecosystems in Europe. Cambridge University Press, Cambridge: 427-444. 
Spassov N. \& GeraAdS D. 2008. - The lastest prehumans of Europe: discovery of a late Miocene hominoid in Bulgaria of about 7 Ma. News 2: 2-4.

Spassov N., TZankov T. \& Geraads D. 2006. — Late Neogene stratigraphy, biochronology, faunal diversity and environments of South-West Bulgaria (Struma River Valley). Geodiversitas 28 (3): 477-498.

Strasser E. \& Delson E. 1987. — Cladistic analysis of cercopithecid relationships. Journal of Human Evolution 16: 81-99.

Strömberg C. A. E., Werdelin L., Friis E. M. \& SARAC G. 2007. - The spread of grass-dominated habitats in Turkey and surrounding areas during the Cenozoic: phytolith evidence. Palaeogeography, Palaeoclimatology, Palaeoecology 250: 18-49.

STRUHSAKER T. T. 1967. - Ecology of vervet monkeys (Cercopithecus aethiops) in the Masai-Ambolesi game reserve, Kenya. Ecology 48: 891-904.

SZALAY F. S. \& DELSON E. 1979. — Evolutionary History of the Primates. Academic Press, New York, 580 p.

Teaford M. F. \& OYen O. J. 1989. - In vivo and in vitro turnover in dental microwear. American Journal of Physical Anthropology 80: 447-460.

UNGAR P. S. 1996. - Dental microwear of European Miocene catarrhines: evidence for diets and tooth use. Journal of Human Evolution 31: 335-366.
Ungar P. S., SCOtT R. S., Scott J. R. \& Teaford M. F. 2008. - Dental microwear analysis: historical perspectives and new approaches in IRISH J. D. \& NeLSON G. C. (eds), Volume on Dental Anthropology. Cambridge University, Cambridge: 389-425.

Walker A., Hoeck H. N. \& Perez L. 1978. — Microwear of mammalian teeth as an indicator of diet. Science 201: 908-910.

Yeager C. P. \& Kool K. 1994. - The behavioral ecology of Asian colobines, in DAVIES A. G. \& OATES J. F. (eds), Colobine Monkeys. Their Ecology, Behaviour, and Evolution. Cambridge University Press, Cambridge: 496-521.

YoulaTOS D. 2003. - Calcaneal features of the Greek Miocene primate Mesopithecus pentelicus (Cercopithecoidea : Colobinae). Geobios 36: 229-239.

Zapfe H. 1991. - Mesopithecus pentelicus Wagner aus dem Turolium von Pikermi bei Athen, Odontologie und Osteologie. Neue Denkschriften des Naturhistorischen Museums in Wien 5: 1-203.

Zazzo A., Mariotti A., Lécuyer C. \& Heintz E. 2002. - Intra-tooth isotopic variations in late Miocene bovid enamel from Afghanistan: paleobiological, taphonomical and climatic implications. Palaeogeography, Palaeoclimatology, Palaeoecology 186: 145-161. 